6-10-2021

\title{
Unity and Variety of Musical Culture of The East
}

\author{
Rustambek Abdullayev \\ The state conservatory of Uzbekistan, rustamabdullayev1947@gmail.com
}

\begin{abstract}
About a kind of renaissance of Uzbek (and, in general, the Eastern) music of its active and diverse in the functioning of our era, the explicit updating its stylistic and expressive possibilities. Evidence of this traditional international music festival "Sharq taronalari" (Melodies of the East) held in Samarkand in 1997.

Keywords: music, festival, East people, culture, genre, history, makom, creativity, national
\end{abstract}

Follow this and additional works at: doi.org/10.52847/EAMSJ

\section{Recommended Citation}

Abdullayev, Rustambek (2021) "Unity and Variety of Musical Culture of The East," Eurasian music science journal: 2021 : No. 1 , Article 5.

Available at: https://uzjournals.edu.uz/ea_music/vol2021/iss1/5

DOI: https://doi.org/10.52847/EAMSJ/vol_2021_issue_1/50

This Article is brought to you for free and open access. It has been accepted for inclusion in Eurasian music science journal (www.eamsj.uz). All copyrights to articles (preprint, postprint and version of record) belong to their authors and do not pass to anyone. PDF versions of scholarly articles are in open access under the Attribution Non-Commercial No Derivatives CC BY-NC-ND licence. 
The abrupt social and cultural rise of Uzbekistan in the years of independence - one of the characteristics of our country. And here is extremely intense dialogue of lively traditions in music. You can talk about a kind of renaissance of Uzbek (and, in general, the Eastern) music of its active and diverse in the functioning of our era, the explicit updating its stylistic and expressive possibilities. The revolutionary transformation of Uzbekistan for thirty years led to a momentous turning point in the fate of the Uzbek national culture. Years of Independence made significant adjustments to the musical picture of not only Uzbekistan, but the entire region of Central Asia and even the world, largely changing the usual relation of forces. Uzbekistan more confidently enters into the world community. And this is a significant fact or may not affect the appearance of the musical map: even now our republic finds fame as a country music truly is increasingly becoming the center of international music festivals. Evidence of this traditional international music festival "Sharq taronalari" (Melodies of the East) held in Samarkand in 1997 on the initiative of First President of the Republic of Uzbekistan Islam Karimov.

Festival is attended by representatives of over 70 countries and international organizations. Within the festival there are competitions of traditional and contemporary performance, concerts and meetings leading singers and musicians, as well as performing groups from many countries from all continents in the Samarkand region and surrounding areas; crafts fairs and art exhibitions, scientific conferences on various issues of oriental music and master classes of famous musicians. All these festivals and competitions contribute to the diversity of artistic culture of Uzbekistan and create an image of our country, highly artistic cultural environment not only regional but also global level. They contributed to the formation of a new Audience perception and performance traditions; they have influenced both the overall musical situation in our country and beyond, and the artistic thinking of many musicians. This festival stimulated creativity of creators and performers, in particular, it raises the image of the traditional culture; the youth awakened interest in traditional and modern music, a taste for experiment, to seek 
new forms and means of expression; a symbiosis of national traditions and modern musical language.

Keeping the old and new mastering, Uzbekistan turned out the owner of the best at the turn of the century set of musical creative types. Today's situation dramatically escalated the search for national self identification, is that in the musical culture of the east of the republic (national) began to show themselves more fully and intensely, and they are represented in all kinds of musical creativity and performance. However, functioning in the common cultural space, the music and creative types are increasingly touching, forming a "single national fund of the genre".

In our troubled world musical art, as well as other areas of art, always bears the stamp of the time; it expressed the tendencies of its time throughout the uncompromising struggle of different worldviews. But this picture of the social and cultural life at the present stage more multidimensional.

Two sides of a common historical and cultural process - the creation of a common identification and nationally unique - the main feature of the art of Orient, detected as the specific side and typological characteristic. However, the deep connection with the rich and unique cultural heritage and synthesis with historically established laws, the broadest interethnic communication and exchange becomes an immutable law of artistic development; factor that accelerates the process of updating national styles, the growth of skill.

Life, art practice, to preserve the tradition assures us that the more closely linked to national culture with other cultures, the more intense it incorporates features of the spiritual and artistic experience of other nations, who have acquired interethnic, intercultural and spiritual value, the quicker and more fruitful it develops, and that it contributes greatly to the enrichment of the spiritual life of their society and even the whole world community.

Review the history of art and traditional culture of the peoples of the Orient as a whole or its individual stages, types and genres rests on two premises: the attribution of works of art (place, time, creators of material, manufacturing 
methods, creation of forms, methods and manners of playing) and the determination of its art advantages (school, style, tradition, the development of artistic images and ideas of the era, media). Today, the music of people of the Orient - multi-genre art, rich in content and means of expression, a truly modern in spirit and character, and at the same time, is firmly grounded in the best traditions of the past. Evidence of this preserve and develop the traditional ritual music and instrumental works (solo, ensemble and orchestra), the national epic - epics and maqom-mugam art; singing and stage works of monodic culture creators (bastakors, kyushi, ashugs etc.) - the active carriers of musical traditions.

Its unique in its nature performing arts as the main direction of the musical culture of the peoples of the East, which crossed dozens of dialects, styles and genres, taking its origins from the depths of centuries. Here the high classic and national treasure - maqam, mugam, muqam, destgahs, raga, kui; a scattering of pearls of folklore - from children's songs to play original song cycles of wedding ceremonies; a variety of musical instruments and original instrumental music, as well as a magnificent national epic - epics. And the fate of the culture of the peoples of the East have always depended on the mechanism of succession of its forms, that is to combine intensive collection and study of traditional heritage with special attention to new trends in the development of modern art while retaining the main criterion - the importance of artistic creativity of the musician, singer, storyteller, bastakor.

The peoples of the countries of the Orient since ancient times, and living at the present stage, consolidated of household, linguistic, cultural and religious community, which affected all aspects of their lives. At all stages of the history of the peoples of Orient the religion pervaded all aspects of society - political, socioeconomic, spiritual, moral and ethical. The new faith, as Islam has become the main source of morality being the norm, the whole way of life. But it was not able to destroy until the end of the old traditional beliefs, moreover, it has absorbed a lot of cults and religious practices of previous eras. This demonstrates the specificity of the religious life of the peoples of the Middle East - this synthesis is greatly 
enriched their spiritual life, absorbing the achievements of people of great confessional space. It correctly noted and renowned orientalist N. I. Konrad: "The history of every nation is always connected with the history of its neighbors ... So, in the history of the peoples of the factors that created it by common historical life" (East and West. M., 1972, p. 17.)

Entered into a single religious space of Arab and other countries of the East, Central Asian medieval thinkers Imam al-Bukhari, Al-Termez Nakshbandi, Mansour al-Matrudi and others made a great contribution to the treasury of the Islamic faith. And the works of well-known scientists - Abu Nasr Farabi, Mohammed al-Khwarizmi, Ahmad al-Ferghani, Avicenna, Abu Rayhan Biruni, Narshakhi, Mirzo Ulugbek and others in all areas of science, as well as the activities of Khorezm Mamun Academy, the Academy "Baytulhikma "Baghdad, Ulugbek Madrasah (as a scientific school) in Samarkand was not only discoveries in the world of science, but also raised the ethno-cultural development of the peoples of the region to new heights.

The IX - early XX centuries - the period when the culture and art, in particular, the musical culture of the peoples of the Orient began to develop in the framework of philosophical, theological and aesthetic ideas of the Muslim world. And today, when there is a global reassessment of the cultural heritage, it appears to identify with the current position of the new historical realities of artistic values created by the peoples of the Orient. Even in ancient times, we are witnessing the integration of musical traditions; evidence of this, ghats - hymns of "Avesta", which laid the foundations of ritual music, including religious-ritual chants in the East. Or the Great Silk Road, which became a bridge of cultural relations between East and West, an example of what the integration of a number of string instruments in Central Asia (oud, kobuz, dombra), which laid the basis for the formation of a number of musical instruments in the West and the Far East, as the lyre, kithara, Lera, lute, the pipa, topshur, viola etc., or a widespread genre of "Tarona" crystallized in the musical creativity of the people of the Orient, as a kind of a tradition of singing (not only in maqom art and folk art). 
At the turn of XX-XXI-st centuries there was the resuscitation is a kind of Islamic values, caused by the growth of national and cultural identity. And musical heritage, centuries-old tradition, is once again becoming an important factor in their identity. For the traditional performance of the culture of Uzbekistan and other nations of the East characteristic melodic, intonation and timbre, rhythmic variety, achieved not only vocal techniques, but also the specific sound of folk instruments that give the songs and poppy dastans unique flavor. The most notable feature of the musical performing arts is a synthetic unity, apart from the main poetry and music, singing with dance and instrumental music with spectacular views of art. Each traditional singing or dance style has its own specific music, rhythm, a particular composition of musical instruments and actors who perform certain functions of the singer, dancer and musician. The traditional word of mouth-professional (or classical) music (Uzbek-Tajik maqoms, Fergana Katta ashula, Khorezm Suvora, epics - Manas, Dombra Kazakh kui, Turkmen dutar Muqam and others.) has been refined; it is put before implementing complex artistic and technical problems whose solutions require multiple talents and virtuosity. For example, in the history of maqoms had many brilliant performers, spiritualize its talent is art. But only a few gave a new direction to maqom within the established traditions. For such a decisive step needs not only talent, inspiration, and a strong will, a deep belief in the right, strong reliance on the knowledge of the theoretical foundations of music, poetry and stories.

Every historical epoch has advanced requirements to the eastern performing arts, and therefore for each particular period of its development characteristics and specific features. By a number of factors, such as humanitarian and ethical consciousness of society, the development of artistic ideas and aesthetics, genre and stylistic trends of searches musical poetry, dance and performing arts, as well as the presence of the richly talented performers and artists, it became the spokesman of the spiritual and moral priorities of his time. Thus transformed, and the very understanding of the performing arts, its objectives, goals, artistic criteria, the specificity of all its areas (music, dance, shows, games). And this work was 
seen in the synthesis of all the arts (poetry, music, plastic arts, action); they elevated to a "sublime", "Divine" or done spokesman complex world of human experience. Performing arts today puts a lot of questions related to the assessment of its nature, values, figurative-expressive means, vocal-technical, musical and performing dance and entertainment universals, the place and importance in the modern world, in a system of universal and national culture.

Performing arts, because of the inexhaustible possibilities of expressive force and emotional and psychological effects, and takes today took a special place in the spiritual life of the East. Carried out in line with local, national (or newly acquired due to the socio-historical conditions) trends, defined as the level, variety of music and poetry, and dance spectacles, and emotional characteristics of the warehouse, psychology, mentality and temperament of each people, it became the the foundation of a national school, in expressing its best, the complex world of human passions and emotions. Decorative art is not only historical roots, but also specific features which are due to the nature of the content and performance culture, the richness of musical and poetic vocabulary, the presence of rich performance traditions. The important role played by the location of the region, the social conditions of existence of the people, the social status of the artist (musician, singer, dancer, askiyachi, bakhshi, ashug, kyuishi etc.), And all the arts in the artistic priorities, the operation of performing schools - "Ustoz-shogird" (masterdisciple).

Focusing on the tradition has become a key point to understand the changes taking place in the music culture of the Orient at the turn of the century. The concept of "tradition" covers various spheres of functioning of musical creativity, the essential features of which have been identified oral form of art (way of expressing heritage, transmitted from memory orally), variance (the main form of existence of separate creations), collectivity (mass), and performance. Established a system of interpretation, systematization and synthesis at the level of culture - is the unity of subjective and objective experience, it is a synthesis of the spiritual and personal, cultural and historical continuum in which formed the system does 
not correct the behavior of the individual and the collective (community) through control of the storage, transmission and teaching methods, but also provides continuity of developed models. As the art system traditional culture is regarded by us as a system of relationships linking a wide variety of shapes, forms, genres and traditions, in the aggregate which are implemented holistically different types of culture (music, dance, applied art, folk entertainment, etc.). And modern science highlights the language of oral communication, giving it a special place in his systematic description of the language situation (system-structural method, or a semiotic approach), that is, the language (verbal or musical) is being studied as a holistic system, which contributes to the disclosure of the studied phenomena. And the oral tradition, generally recognized as a major property of folklore, opposes it to written culture.

Language of the oral tradition represented as a special specific language, hence the phenomenal represented, for example, the ability of carriers epic folk traditions, fertile memory of tens and hundreds of thousands of lines of poetry complex poetic text, not to mention the musical melodies, example of this creativity of Kyrgyz manaschy, Uzbek and Turkmen Bakhshi, Azerbaijan ashugs, Kazakh and Karakalpak zhyrau. The same we can say of the executors of maqom traditions of art, for example, the Uzbek-Tajik "Shashmaqom", Uyghur Muqam, Azerbaijan mugam, the Iranian destgah etc., Performers are stored in the memory not only the numerous amount of poetic text, but many melodies, rhythms-usuls, forms the works, as well as a kind of culminations (Auj) and improvisation in the high register. Live epic, or other genres of oral tradition suggest other than linear, for example, generation algorithms - memorization and reproduction of texts, more economically and efficiently use the resources of the creative memory of the storyteller or a musician-singer. Prior to the oral tradition of the masters of almost unlimited possibilities of large-scale folding and unfolding epic canvases as "Manas", "Alpamysh", "Yor Targyn", "Shahnameh" et al., Or such multipart vocal and instrumental cycles as Macs, Taksim, mugams, instrumental kui or raga. 
The socio-cultural stratigraphy of modern, such as musical life is extremely mobile on the one hand, the degradation of orally-professional (classical) art with their return to the folk-soil culture or in amateur (for example, the Central Asian republics); and on the other, on the contrary, professional musicians writing orientation seek to understand the rules of interpretation of music-making to the canons of traditional culture (case in point, the practice of folk ensembles in the professional creative associations). Hence, two types of operation activities: the first - an anonymous, impersonal work of folk type; the second - the author's personal-type work. On the basis of this classification, there is the most natural sequence of signs of oral tradition: the social conditions - mental awareness artistic result. The artistic level is only definitively establishes the achieved results. This structural stratification of musical practice indicates the presence of regulated social relations, what has caused the presence of regulatory and functional spheres of musical art that reflected even in the special musical treatises of the Middle Ages, in the classical eastern literature, philosophical works, and now in the different fields of musicology (folklore study, oriental study, organalogiya, iconography, etc.).

In traditional cultures of the peoples of the Orient, there are quite took shape performing schools and artisan craftsmanship, transmitting over many generations oral music, entertainment and artistic traditions with the help of elaborate systems, in modern language teaching methods (technologies), where you can discover all the features of the existing pedagogical process "Ustoz-shogird" (master-disciple), from coherent system of theoretical knowledge to specific technical exercises allow to master the techniques and skills of singing or playing a musical instrument, vocabulary and verbal patterns of poetry. For example, techniques of playing dutar, saz, lute or kobuz for the narrator - Bakhshi - zhyrau or ashug were so sophisticated, and the importance of music in the eyes of society so high that students may spend a year on the acquisition of only one performing virtuoso technique. Traditional channel skills from teacher to student is as follows: Master (Ustoz, ustod) transmits its accumulated knowledge fund student, as they say, "at 
their fingertips" by demonstrating their skills. Generally, this knowledge and transfer method envelops mystery. Aspiring musician or bakhshi many years spent in daily communication with their teacher before receiving a blessing from him fotiha or stalemate - the equivalent of an unwritten official "certificate" giving the right to an independent creative and performing activities. At the turn of the century in the context of protection, conservation and development of the musical heritage of most of the canons portrayed verbally, that is all "learning rules", in this case, transmitted through teaching "Ustoz-shogird." For example, a school development "Shashmaqom" as written sources was guided only Bayaz collections of classics of oriental poetry, where a certain poetic text (gazelle) attributed to a particular tune. This fact indicates that the system "Ustoz-shogird" in the heyday of maqom art reached its highest perfection. And now one of the challenges of the XXI century - is the restoration of the traditional system of apprenticeship schools, which no doubt will ensure the prosperity of music and performing arts in modern conditions (taking into account the modern system of musical education).

"This tradition - as noted composer Igor Stravinsky - is not evidence of the vanished past, on the contrary, it is a living force, toning and informs the present".

Today, the traditional musical culture of the peoples of the Orient associated with the concept of "intangible cultural heritage", which includes monuments of musical and poetic, entertainment and dance, traditional crafts, folk ceremonies and holidays. In recognition of the peoples of Orient to the world civilization was the decision by UNESCO since 2000, the program "Masterpieces of Humanity" and the inclusion of such unique phenomena of musical culture as "Azerbaijan Mugam", the Kyrgyz epic "Manas", Uzbek-Tajik "Shashmaqom", Mongolian epic "Tuuli", Ferghana "Katta ashula", Indian raga, a national holiday "Navruz" of seven countries (Azerbaijan, India, Iran, Kyrgyzstan, Pakistan, Turkey and Uzbekistan) and others into representative list of UNESCO.

Having a rich cultural heritage, to bring it to the present day and to transmit to future generations - is an honor for every nation, as people are not inspired by 
the material and spiritual wealth. From this perspective peoples of the Orient since ancient times have many cultural richness and the enormous importance of culture, particularly the music culture of the peoples of the Orient, and a testament to the celebration of the most ancient national holiday Navruz (Novruz Navryz etc.) personifies the whole spirituality of the nation ranging from the mythological representations of ancestors to the views of his contemporaries. Navruz - spring festival like many peoples of the Orient, who came to us from time immemorial, is one of the jewels of the unique creativity, the owner of the unique creativity, preserves many of the traditions and cultural values. In March 2015 more than 12 countries (Azerbaijan, Afghanistan, India, Iraq, Iran, Kazakhstan, Kyrgyzstan, Pakistan, Tajikistan, Turkey, Turkmenistan and Uzbekistan) have applied for inclusion in the new list of the Intangible Cultural Heritage. Maqom art in the history of the peoples of the Orient also has deep roots and plays an important role in the oral heritage of musical culture. There are a number of general properties of the Uzbek-Tajik maqam with Azerbaijani mugham, Iranian destgah, Uyghur Muqam, Arabic maqam, Maghreb noobies, Taksim Turkish and even Indian ragas, which make them akin to that in the general forms of social and artistic traditions of Eastern music. Evidence of this, the activities of carriers and performers of maqom art as well as composers, poets and artists of the East, whose Maqammugam are constant and never-ending source of inspiration. After maqom art for the people of the Orient- one of the main cultural values forming the basis of their national consciousness and identity of nations.

The process of saving musical values - it is a matter of great importance. In recent decades they have become part of a huge cultural heritage, which in the past were available for election, and now - and the general public. The media have become one of the cultural spheres of space and time in which we can listen and enjoy the music as a past and modern musical opuses. This is not to shun the real sound and music. And here I like to mention the activities of international companies in the conservation and restoration of a number of native musical traditions of the East. After all, music has always sounded like a confidential part 
of the people's soul, whoever she was created as a higher musical and poetic and philosophical generalization of world folk performances.

All this plays an important role in the formation of historical memory, the strengthening of national identity and community of traditional culture. The importance of this event is undeniable - it is the traditional culture of the peoples of the Orient shows an example of the formation of a new universal community based on the principles of the transcontinental symbiosis.

Great Hafiz was right, saying that "life has entered into the human body through music, but the truth is that life - there is the music itself".

\section{References:}

[1.] Abdullaev, R. (2015). The Characteristic Features of the Oral Tradition and Dastan as Elements of the Intangible Cultural Heritage of Central Asia. Safeguarding the creative value of Intangible Cultural Heritage in Central Asia, focusing on Oral Traditions and Epics. Samarkand. pp. 12-33.

[2.] Abdullaev, R. (2008) Uzbekskaya traditsionnaya muzika kak chast sovremennosti [Uzbek traditional music as part of modernity]. Uzbekskaya Muzika na Stike Stoletiy (XX-XXI Vv.): Tendentsii, Problemi [Uzbek Music at The Turn of The Century (XX-XXI Centuries): Trends, Problems]. Tashkent, pp. 9-38.

[3.] Abdullaev, R. (2015). Intangible Cultural Heritage Safeguarding Efforts in Uzbekistan. Seul.

[4.] Abdullaev, R., Tashmatov, U., Eshonqulov, J., Ashirov, A., Khakimov, A. (2017) Intangible Cultural Heritage of Uzbekistan. Tashkent. 